\title{
The State of Service Related Competences in Montenegro
}

\author{
Jelena Šaković Jovanović, \\ University of Montenegro, Montenegro \\ Sanja Peković \\ University of Montenegro, Montenegro \\ Branko Bošković \\ University of Donja Gorica, Montenegro
}

\section{Abstract}

European business sector pays more increasing attention ever to competences, such as the sense of initiative and Service related skills. Social, Personal, and Organizational Competences are becoming competitive factors in the service economy, even though these competences are mainly being acquired in informal contexts. Still, there are no opportunities to acquire these competences at most universities. It was the main reason for conducting research and developing the Erasmus+ project E-VIVA project, with the aim to develop a learning approach for Service Related Competences in Higher Education. The University of Montenegro and the University of Donja Gorica are involved as partners on the E-VIVA project in the research of the state of the art of Service Related Competences in Montenegro. Accordingly, the two institutions performed joint research in the field through three instruments: desk research, online questionnaires, and an interview. Target groups for the research were: students, HEl, enterprises, administration, Chamber of Commerce. In this paper, the results of the research are presented, with a special focus on results obtained in online questionnaires. The main reason for that research is to evaluate a current state of Service related competences in Montenegro and to develop a model for the improvement of these competences in Higher education, in order to improve the employability of future graduates.

Keywords: entrepreneurship, innovation, desk research, questionnaire JEL classification: L26

Acknowledgments: Erasmus + project "Enhancing and Validating service related competences in Versatile learning environments" "E-VIVA" co-funded by the Erasmus+ Programme of the European Union.

\section{Introduction}

A difference has been made between products (which are material) and services, prior to the release of ISO 9000:2000 standard. Upon introduction of the standard, a product is now used in its generic sense. Products and services are often connected to what companies offer. Hence, a constructor of machines and tools ensures an after sale maintenance, as well as sometimes embedding in user's places, commissioning, and training of operators. Opposite to this, a hotel - restaurant provides services may also comprise delivery of products. Therefore, a pair product - service is becoming more attractive (Maxwell et al., 2003; Oliva et al., 2003).

Comprehensiveness and complexity of a service, namely its representation in the total economy in the World, gives it a strategic significance to this category, with 
growth to $55 \%$, in relation to industry and agriculture, which participate with $45 \%$ (Vojnović, 2008). There is a prediction that services will be represented in the global economy, with $85 \%$.

There are several definitions of services. According to the ISO 9000:2015 standard, services can be defined in the following ways: "Service often involves activities at the interface with the customer to define customer requirements as well as upon delivery of the service and can involve a continuing relationship such as banks, accountancies or public organizations, e.g., schools or hospitals." Provision of a service can involve, for example, the following: (i) an activity performed on a customer-supplied tangible product (e.g. a car to be repaired); (ii) an activity performed on a customersupplied intangible product (e.g. the income statement needed to prepare a tax return); (iii) a delivery of an intangible product (e.g. the delivery of information in the context of knowledge transmission); and (iv) a creation of ambience for the customer (e.g. in hotels and restaurants).

Services can also be defined as products that are, by the rule, of non-material nature such as, e.g. transport and similar (Krivokapić, 2008). It can be a result of at least on activity in relationship deliverer and user (Vujović et al., 2014).

Service economies in developing countries are mostly concentrated in financial services, hospitality, retail, health, human services, information technology, and education (Szirmai et al., 2015). The dominant elements of a service are generally intangible, and they are, in most cases experienced by the customer (International Organisation for Standardisation, 2015). However, the production sector should not be distinguished from the service sector since there may also be services related to the products (e.g., in the IT sector) and may require service competences for quality performance (Cooksy et al., 2005).

The University of Montenegro and the University of Donja Gorica, as partners on the EVIVA project, are involved in the research on the status of service related competences in Montenegro (E-VIVA project, 2018). Accordingly, the research was conducted, and it consisted of three parts: desk research, online survey, and focus group. Target groups for the research are students, HEl, enterprises, administration, Chamber of Commerce.

\section{Methodology}

\section{Desk Research}

The desk research on service related competences in Montenegro was conducted by professors of the University of Montenegro and the University of Donja Gorica. The desk research encompasses 4 topics as the following:

- Part 1: Service Related Competences in practice

- Part 2: Service Related Competences in Higher Education

- Part 3: Learning Technologies and blended learning in Higher Education

- Part 4: Job related Competences, Informal learning, and Validation

\section{Focus group}

The focus group was performed with 1 entrepreneur (business person), 2 professors (the University of Montenegro and University of Donja Gorica), 2 students (the University of Montenegro and University of Donja Gorica) and 1 member from the Chamber of Commerce. There were 5 questions (each with more than 1 sub-question) as the following. 


\section{Online survey}

EVIVA is a research and development project addressing the issue of students' skills development, facilitation, and validation of their skills in informal learning contexts. The project aims at the identification of the most fundamental competences for a service economy, and it will contribute to higher transparency of these, for students, teachers, employers and any other subject interested in it [E-VIVA project]. Informal learning contexts are gaining on the importance, and the project will identify main issues and will contribute to the further advancement of new ways of learning [E-VIVA project]. The Online Questionnaire was distributed to all partner countries at the Erasmus + EVIVA project. It consisted of 5 parts: Introduction and statistical background data, Service Economy and Service Related Competences, Acquisition of Service Related Competences, Validation of competences, and Digital learning

\section{Results}

\section{Desk research}

Some of the most relevant findings are presented in the following text, and they tackle the following issues:

- Service Related Competences in Practice

- Service Related Competences in Higher Education

- Learning Technologies and Blended Learning in Higher Education

- Job Related Competences, Informal Learning, and Validation

Service Related Competences in Practice

The basic strategic branches of the Montenegrin economy are based on services, especially in tourism, transport, as well as on agriculture and its service processes. Montenegro has recognized its potential in the development of the service sector and had changed its strategic direction of development. The economy is being restructured from the production oriented to the service oriented enterprises, through reorganization of the economy. The state bodies promote a necessity for collection and validation of competences referring to service and other sectors.

The needs of the business sector in Montenegro contributed to the promotion of dual education in high schools, especially in the service sectors such as tourism and hospitality. It happened mostly because Montenegro is a well-known tourist destination, and the tourist product is financially important for the state budget. The business subjects also frequently appear as initiators for the development of certain studies, i.e., educational program. They define levels of the required knowledge, competences, and skills, i.e., studying outcomes to be mastered by students or pupils, and it is relevant both for service business sector and in other areas.

All the competences, acquired at higher (and lower levels) of education are collected, analysed and adopted, and thereafter classified in the national qualification framework aligned with the European qualification framework, through the body of the National Qualification Council, as well as sectoral commissions.

\section{Service Related Competences in Higher Education}

The study programs at the higher education are implemented in accordance with market requirements, i.e., requests of the business sector. Namely, the competences acquired during the creation of certain study program must be proved as convenient to be used at the market, i.e., must satisfy the business sector requirements.

There is no specialized educational program in the state for the development of "service-oriented competencies," but these competencies are developed especially 
for specialized fields, such as tourism, hotel management, economy, law, foreign languages, etc.

Learning Technologies and Blended Learning in Higher Education

There are no official statistics available on the use of learning technologies at universities. However, depending on a specific faculty, there is an application of some services on specific courses. They refer mostly to faculties which are more practice oriented, requiring laboratory research and precise results which cannot be obtained in any other way. The courses are organized on the use of the methodology that goes beyond lecturing. Apart from using the software, teaching is being increasingly organized around students' needs and their future development. It means that the basic modality of learning improves students' capabilities through investment in not only their knowledge but also in their life intensity.

There are no universities or faculties specialized in delivering blended learning. However, there are activities which are undertaken during research projects, which aim to develop a new approach or technology that can be used at universities. Some of these are intended for exclusive use in projects while others may be convenient for a wider audience, especially teachers and students. Unfortunately, there is no database on these activities at each university, nor even at faculties.

In accordance with the law, faculties are obliged to provide $25 \%$ of the education in practice, and there is an increasing number of cooperation between universities and the private and public sector. Accordingly, the University of Montenegro established a plan of teaching for the purposes of organizing practical classes in some companies where practical training will be conducted. Some of the major examples are identified in section 2.5.

The University of Donja Gorica has developed a special project for students, called Ideas and Character, and all its students are obliged to participate. They are given an idea of the project at the beginning of every semester, and they work in groups and prepare presentations.

\section{Job Related Competences, Informal Learning, and Validation}

Validation of competences is essential for HE institutions because it enables them to know which competences, knowledge, and skills they are developing. Creating study programmes depends essentially on understanding, which competences students will develop; hence, the criteria for the development of courses are defined in accordance with these rules. On the other hand, the private sector, together with public institutions, utilises the existence of these rules, based on understanding what type of knowledge, competence, and skills they can expect from prospective employees.

There is no validation system for vocational training and similar educational options. Employers in the private sector look for these types of education, especially, because they provide additional skills, which are often ahead of what HE institutions offer. Some of the vocational training is offered by the Employment Agency of Montenegro, through active labour market policies, but statistics are only available on the yearly level, with no specific information about persons who participate. However, the invidiuals' participation is recognised officially, although there is no system of validation.

\section{Focus group}

Results of the focus group are targeting the following issues:

- The general demand for education on Service Related Competences 


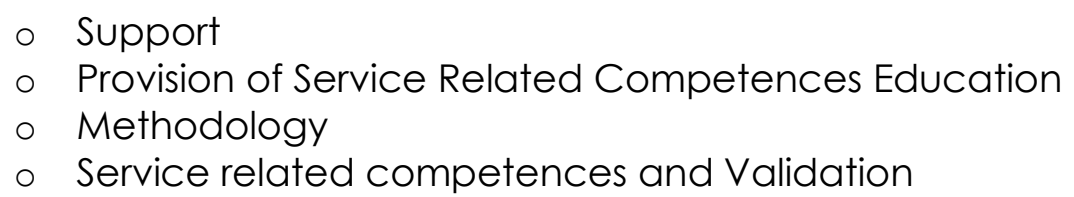

The general demand for education on Service Related Competences

All respondents agreed that the demands for education where service related competences are acquired were very significant in size. It is especially evident from the number of students enrolled in faculties such as economics, tourism and hotel management, etc. In addition, it was noticed that at a higher level of studies, i.e., at master's studies, at the Faculty of Economics, a large number of students who have completed technical studies, enrol and are interested in widening their competencies in the field of a service economy.

Most respondents agree that there are programs and modules for acquiring university knowledge related to achieving service related competencies. For secondary and elementary education, there are also modules and programmes for acquiring knowledge in the field of service related competencies. Such an approach has been particularly pronounced in the recent period, when, through the reforms and primary, secondary education, and especially university education, the importance of developing outcomes related to service related competencies was recognized.

All the respondents agreed that the orientation to a user was imperative for the development of the entrepreneurship and development of entrepreneurial learning. In general, attitudes and behaviours in Montenegro have been revived in accordance with the principles of user orientation, and it is necessary that this approach is applied and transmitted through education, as well as to younger generations.

\section{Support}

According to the opinion of our respondents, employers and, generally, the business sector, must be in some way directly involved in the teaching process, based on precisely defined contractual obligations. It is especially important in this process to co-opt former students in the business sector, so - called Alumni. This model would have to be developed, especially through the creation of the so-called - Alumni organization, as well as through so-called Teaching bases or organisations in which practical teaching would be conducted.

Based on the students' attitudes and the experiences of the professors, it can be concluded that the student population appreciates especially the necessity of involving experts from the real sector into the teaching process.

The Higher Education Strategy envisages the development of Service Oriented Competencies, in particular through the audit of learning outcomes, which, in large part, must be oriented towards practical knowledge. In accordance with it, our respondents agree that Montenegro's strategic commitments are greatly applied, with the particular emphasis on the importance of service orientation, especially in the area of tourism, as well as agriculture and transport.

\section{Provision of Service Related Competences Education}

The higher education institutions must work additionally, in order to improve the conditions for the work of students and professors, primarily in the area of infrastructure, as well as the equipment. This includes the formation of better library funds, with more recent, international literature, oriented to new experiences in the areas of Service Related Competencies. In addition, higher education institutions need to establish 
better relationships with the economic sector in order to identify the needs for the new knowledge and technologies needed for development.

According to the opinion of the respondents, foreign organisations and companies would have to take a greater role in the formation of the Service Related mind in Montenegro.

\section{Methodology}

Most of the interviewees think that the education for service related competences have to be realised during the school education, but also at the faculties. However, it is necessary to organise educational seminars for the elderly in order to ensure service related competences for this population. The entrepreneurs and representatives of the Chamber of Commerce also consider that similar, continuous training of employees, during their working engagement, is very important. They also agreed that the Chamber of Commerce is the most qualified institution to realize these training, but they can also be organised by the enterprises.

All the respondents believe that practical training is the best way of acquiring service related competences. If service related competences are acquired through the teaching process at the University, it is necessary to establish cooperation between enterprises and the University, because learning through practice is the most useful learning. The attitude of all interviewees is that student internship can be good practice and should be more established.

\section{Service related competences and Validation}

All the interviewees believe that creativity, communicativeness, team spirit, and flexibility are the most important for the realisation of service activities. They also believe that human resources are the most important resource for the enterprise because the creativity of the employees creates a basis for sustainable development of enterprises. All the interviewees think that the assessment of entrepreneurial competences should be realised by some tests and/or interviews.

They think that it is very useful to certify Service Related competences because certification is a proof of the competence. All the respondents agree that acquired service related competencies have to be documented. Also, the documents or certificates issued have to be recognisable on the labour market. In addition, the majority of respondents believe that the certificates issued must have detailed descriptions of the training conducted and that they should be issued by an accredited or authorised institution. However, all the interviewees are not familiar with the framework for validation of Service Related competence.

\section{Online Survey}

There were 80 responds from Montenegro, which is $18.06 \%$ of the total sample. The highest number of respondents were younger than 30 (47.5\%), and that, in the total sample, there were $86.25 \%$ of respondents younger than 50 . In addition, the highest number of respondents, $81.25 \%$, comes from the area of higher education, i.e., students and professors.

Most of the respondents (96.25\%) consider "service related competences" for personal development to be important, while only $3.75 \%$ of them considered them unimportant or they were not sure about their importance. In addition, most of the respondents (93.75\%) consider "service related competences" in relation to "Finding a job" as important, while only a small number of them, as little as $2.5 \%$, does not consider these competences as significant for finding a job. All of the respondents 
(100\%) consider Service related competences in relation to further career development as important.

Based on the analysis of figure 1, it can be observed that the highest number of respondents (48.75\%) considers communicativeness as the most important aspect of service related persons. One-fifth $(20 \%)$ thinks that the orientation towards a user is the most important for service related persons. Other aspects, such as cooperation, critical thinking, customer orientation, etc., were assessed as the "most important" from less than 10 respondents.

Figure 1

The Aspects and Competences That Are Considered as the Most Important for Persons Who Are "Service Related."

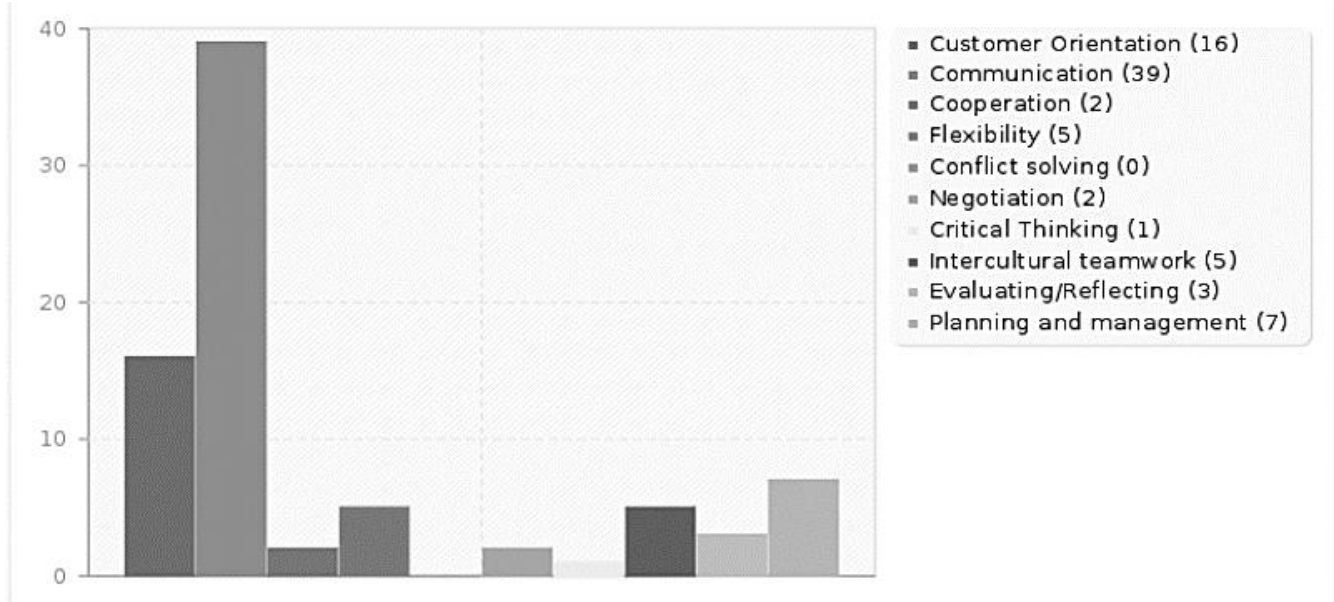

Source: Authors' work

As E-VIVA project has the aim to validate acquired service related competences both for the professors implementing the project and for the students, which will be included in the training through the project, then the questions about the validations of these competencies, could be found as well.

The highest number of the respondents $(47.5 \%)$ has no idea about what the competence validation could encompass, $45 \%$ of them have certain knowledge about that, while only $7.5 \%$ are familiar with the competence validation. In addition, $70 \%$ of the respondents find the validation of these competences as important, and only $6.5 \%$ of them consider it as unimportant, while $23.75 \%$ are not familiar with it at all.

\section{Conclusion}

Service related skills and Social, Personal, and Organisational Competences are becoming competitive factors in the service economy. Most universities do not provide specific learning in this context, and there are no opportunities to acquire these competences. At the same time, there is no evidence for service related skills and competences for persons who acquired them outside the higher education sector. This was the main reason for the initiation of E-VIVA project. The research was conducted through E-VIVA project, and it is presented in this paper, showing the current state of the art of the area in Montenegro. The findings support the need for further and additional, work both on acquiring knowledge and on the validation of service related competences.

According to the results presented in the three parts of the research, we found that in Montenegro has not seen significant efforts to make preconditions for the development of service related competences for a long time. However, there is room 
for improvement in this field. Namely, the research showed that more interest in the improvement of these competences could be observed in the recent period.

It refers to young people who are about to go to a secondary school or a faculty and among entrepreneurs during the selection of their cadre. The needs of the business sector in Montenegro have led to a promotion of dual education in secondary schools, especially in service activities. However, since there are no specialized educational programs for the development of "competences oriented to services" in high schools or universities, these competences are being developed separately for specialized areas such as the areas of tourism, hotels, economy, law, language, etc.

The research showed that the service related competences are considered to be very important in all professions, both for finding a job and for further career development. The same refers to the validation of competences. In a similar vein, there is a need that these competences are more developed in areas where they do not have the prime relevance now. The need for validation of these competences was recognised by the majority of respondents.

The aim of the E-VIVA project is to enable incorporation of a module of learning about service-oriented competences into the educational programs at the University of Montenegro and the University of Donja Gorica. Creating the conditions for the improvement and validation of service oriented competences of students for the purposes of their faster learning and more quality inclusion on the labour market will be in focus in the forthcoming period.

\section{References}

1. Cooksy, L. J., Caracelli, V. J. (2005), "Quality, context, and use: Issues in achieving the goals of metaevaluation", American Journal of Evaluation, Vol. 26, No. 1, pp. 31-42.

2. E-VIVA project (2018), available at: https://evivaproject.eu/ (22 July 2019).

3. International Organisation for Standardisation (2015), ISO 9000:2015, Quality management systems - Fundamentals and vocabulary.

4. Krivokapić, Z. (2008), Sistem menadžmenta kvalitetom, Mašinski fakultet Podgorica.

5. Maxwell, D., Van der Vorst, R. (2003), "Developing sustainable products and services", Journal of Cleaner Production, Vol. 11, No. 8, pp. 883-895.

6. Oliva, R., Kallenberg, R. (2003), "Managing the transition from products to services", International journal of service industry management, Vol. 14, No. 2, pp. 160172.

7. Szirmai, A., Verspagen, B. (2015), "Manufacturing and economic growth in developing countries, 1950-2005", Structural Change and Economic Dynamics, Vol. 4, pp. 46-59.

8. Vojnović, B. (2008), "Upravljanje kvalitetom usluga", Ekonomske Teme, Vol. 3, pp. 181194.

9. Vujović, A., Perović, M., Krivokapić, Z., Jovanović, J. (2014), Industrijski inženjering, Univerzitet Crne Gore, Mašinski fakultet Podgorica. 


\section{About the authors}

Jelena Šaković Jovanovic has Ph.D. at the Faculty of Mechanical Engineering Podgorica. She is an Associate Professor at the University of Montenegro. Her research interests are focused on the fields of Managements System standards and Performance Management System. She was a consultant in more than 15 projects related to Management Systems implementation according to ISO 9001, ISO 14001, ISO 17025, ISO 17020 standards, and HACCP. She has been engaged in many scientific research projects. She has published more than 40 articles in international journals and international conferences and more than 50 articles in national journals and national conferences. This author can be contacted at sjelena@t-com.me.

Sanja Peković has a Ph.D. in Economics from the University Paris-EST. She is an Associate Professor at the University of Montenegro. Between 2006 and 2011, she was a Researcher at the Center for Labor Studies (Centre d'Eudes de l'Emploi) and a Lecturer at the University Paris-EST. In 2006, she obtained a Master's degree from the Ecole Nationale Des Pontset Chaussées and the University of Paris-EST Marne-la-Vallée. Her research interests are focused on the field of quality and environmental economics, the economics of innovation, applied econometrics, and on this topic, she has published in international journals. This author can be contacted at psanja@ucg.ac.me.

Branko Bošković has a Ph.D. in Political Sociology at the University of Donja Gorica. He is an Assistant Professor at the University of Donja Gorica. He teaches courses: Introduction to Politics, Sociology, Political Sociology, and Introduction to Globalisation. His main research is the welfare state changes development in Europe, with the focus on social investment. He is a member of the Committee for Sociology and Philosophy at the Montenegrin Academy of Sciences and Arts and is a coordinator of Erasmus+ E-VIVA project and Scientific Communication Manager on ENTAN 18114 COST Action. His publications include relevant studies in international journals as well as a book ("Political Sociology of Anthony Giddens"). This author can be contacted at branko.boskovic@udg.edu.me. 